\title{
Some socio-geographic characteristics of modern labor migration from Serbia and Montenegro to Denmark: social life and social relations migrants
}

\author{
Goran Rajović \\ Street Vojvode Stepe 252, Belgrade, Serbia \\ Phone: 003861/19-24-850 \\ E-mail address: dkgoran.rajovic@gmail.com
}

\begin{abstract}
This paper discusses some socio-geographical characteristics of contemporary labor migration from Serbia and Montenegro in Denmark, analyzed in terms of social life and social relations of migrants. At the beginning of the sixties, slow economic development of the country (former Yugoslavia), caused the decision of the Serbian and Montenegrin workers to go abroad. Among these countries, it was certainly and Denmark. Serbian and Montenegrin communities of migrants, although not many (about 8,000), is interesting for researchers, because in the middle of Denmark that is economically dependent, maintained their ethnic or social identity. Since the notion of a complex identity, it must be viewing within the more theoretical approach or framework. Therefore, there are two interpretations: one given by the respondents, and other researchers. In this study, on the one hand the most outstanding are moments in the life and character of the Serbian and Montenegrin man in the time immediately preceding the external migration to Denmark and on the other, new life and a different occupational mobility of respondents. Among the latter, include, for example, communication between Serbian and Montenegrin migrants with their homeland through: print media, broadcasting, internet. Important place in the identification of the Serbian and Montenegrin migrants are in the family, relatives, churches, associations and clubs, where they can develop their activities. Thus, forming a social network within the community and are wider environment.
\end{abstract}

Keywords: The migrants from Serbia and Montenegro; Denmark; external migration; social life; social relations

\section{INTRODUCTION}

Economic development does not state, poor living conditions, lack of employment, the most important reasons why people decide to leave their country. Famous economist J. K. Galbraith migration is interpreting, as "the oldest action against poverty". Under the expats, include persons who leave their country in search of better living conditions. This land abandonment is usually more permanent nature (for a long time, and quite often permanently), but that the eviction can occur for various reasons (economic, political, family ...) (Group of authors, 2006).

In the second half of the twentieth century, there was an exodus of labor from Serbia and Montenegro in the various countries of the world. Former Yugoslavia, has failed to create 
a reliable economic and social system, and provide safe opportunities for work and a dignified life. Like many times before, the workforce from Serbia and Montenegro went in the direction of expansion of global capital (the U.S., Australia, New Zealand, Germany, France, England, Sweden, Denmark ....).

Some could not in the system without rules, find their economic position and went, in search of bread, in the wealthier areas. Second, they had the knowledge and security that they can succeed in the toughest environments, so they went in order to secure a life, what in the world labor market and merit, avoiding completely insecure and uncertain penetration in the country of origin (Vukčević, 2006).

The exact number of displaced population in Serbia and Montenegro and their descendants around the world, for sure, that we do not have definitive data. According to the census of 2002 the population of Serbia, has registered 414,839 Serbian citizens living abroad for more than one year (Penev, 2008). However, given the estimated number of migrants abroad Serbian origin far higher at around 3, 5 and 4 million, accounting for almost half of the local population ( Grečić and Petronijević, 2007).

According to the census of Montenegro in 2003, 54,816 citizens of Montenegro is temporarily working abroad, which is $8.84 \%$ compared to the total population of Montenegro. Various sources mention a figure of 90,000 to 120,000 Montenegrin migrants. However, the exact number of displaced population in Serbia and Montenegro and their descendants around the world, it is certain, that we cannot have definitive data.

The fact is that there is no institution in Serbia and Montenegro, which has accurate data on the number of migrants from Serbia and Montenegro abroad. All agree that the number is not small, and that is increasing every year.

Embassy of the State Union of Serbia and Montenegro in Copenhagen in early 2005, an estimate that lives in Denmark about 6,000 migrants from Serbia and around 2,000 migrants from Montenegro. By telling the ambassador of the State Union Serbia and Montenegro in Copenhagen Vladimir Radulović: "It's hard to say how many of our people have the citizenship of Serbia and Montenegro, because in the meantime $40-50 \%$ of them accepted the Danish nationality, which is why they had to give up their previous citizenship, as Denmark does not allow dual citizenship" (www.blic.evropa.net).

Communities of migrants from Serbia and Montenegro, but not many (about 8,000), is interesting for researchers, because in the middle of Denmark that is economically dependent, maintained their ethnic or social identity. "Since the notion of a complex identity, it must be viewed within the more theoretical approach or framework.

Therefore, there are two interpretations: one given by the respondents, and other researchers.

The theoretical framework implies that, if the study of collective identity, its basis is the individual" (Haider-Labudović, 2007). Were taken into account all three generations of migrants from Serbia and Montenegro, and the survey covers the period from the beginning of the sixties, this is the first generation of the arrivals of Serbian and Montenegrin migrants to Denmark, to the dissolution of the State Union of Serbia and Montenegro 2006 year.

\section{RELATED WORK}

Although the social need for migration research (especially its essential components emigration) in Serbia and Montenegro unchallenged, we are not on the plan able to meet their own current and other needs. In this respect, far behind are European and even neighboring 
countries. Scientific analysis of the problem was so far, neglected to illegal proportions. In fact, this is a scientific issue so far treated more informative, without enough reliable data (Rajović, 2011 b).

Geographical Research in Serbia and Montenegro dealt largely problems of external migration before World War II, especially those in overseas countries, Diaspora, questions of status and identity of national minorities in neighboring countries. However, the departure of workers (guest workers) from this space for temporary work abroad after World War II, he was a frequent subject of not only geographical but also historical and anthropological studies. Rightly Marković (2005) notes "the Serbian ethnology and anthropology, as well as the social and cultural history, they avoided this topic." This topic is avoided and social geography. "Only after the departure .... workers became massive, this problem has proven to be encouraged to think and ... Scientific treatment of the problem of temporary labor from the former Yugoslavia abroad, mainly in Germany, started with the first (1967) Geographical Institute of the University of Zagreb, with a small number of associates from the former Yugoslav republics "(Rodić, 1972). So they created Studies Baučić (1970) and Rodića (1971). During the time of former Yugoslavia, geographical studies, which were relating to emigration mainly, focused on the United States, Australia, Canada, and Germany. In addition, usually have this theme more concerned with geographers from Croatia and Slovenia. As was the case with are geographical research in Serbia and Montenegro. Therefore, we - in Serbia and Montenegro still have no geographical literature in scientific papers on immigrants from Serbia and Montenegro in Denmark. They were the main motives and reasons, which I was guiding in the selection, presented topics. Therefore, this is the first work of its kind geographically.

In fact there are several important scientific papers mostly from other scientific and not the geographic disciplines that treat the problem of emigration from Serbia and Montenegro abroad. In which expatriates working temporarily in Denmark are mentioning only in passing. In this respect, they are certainly significant published by: Pejović (1962), Drljača (1963), Božović (1968), ), Rodić (1971), Rodić (1972), Lutovac (1975), Grečić (1975), Majstorović (1979), Petković (1988), Petrović (1990), Davidović (1994), Grečić and Lopušina (1994), Srdić-Đoković (1995), Grečić, Kutlača, Matejić and Mikić (1996), Gabrić Molnar (1996), Davidović (1999), Pavićević (2004), Group of authors (2006), Vukčević (2006). Existing archival material (although still insufficiently treated) indicates mass emigration from Serbia and Montenegro, which, with more or less volatility, as it were, continually exercised. According to these authors the main motive for emigration from Serbia and Montenegro, there is a lack of development in their economies, and thus their inability to absorb the "own" population (Kalezić, 1976).

As for the lack of literature, as well as the fact that until twenty years ago, there was not a comprehensive text, which treated complex problem of emigration from the territory of Serbia and Montenegro in Denmark. It was not until 1993, appeared the first reviews the Montenegrin Diaspora in Denmark. It is a book V. Rajovića "Montenegrins in Denmark." Of the book provides informative historical - sociological view eviction from Montenegro to Denmark and makes a modest contribution to the understanding of this issue, and we have as such and used in our study. Further, research emigrants from Serbia and Montenegro in Denmark, continued the author of these lines because of the work was created monograph "Montenegrin immigrants in Denmark" (2011 a) and the article "Demographic characteristics of contemporary labor migration from Montenegro to Denmark" (2011 b). We hope that continued research of contemporary labor migration from Serbia and Montenegro, Denmark, 
replace the current lack of geographical study and underline the importance of a geographical perspective in the study of social identity, migrants from Serbia and Montenegro in Denmark.

\section{RESEARCH METHODOLOGY}

"A valid method that it is the shortest route, to achieve the desired goal" $R$. Descart. Starting from these observations R. Descartes, we want to emphasize that the methodology in this work is not an end in itself, but as a whole and organically related to the topic title, and is functionally subordinate to the declared goad. Therefore, the pure "discussion method" seems in the context of the above, do not make sense, even more so, because we feel that a unique and universally applicable methodology "recipe" for studying complex process no external migration, which means that the above purposes, cannot be adequately applied and methods inherent in certain scientific disciplines (Banović, 1982).

Without analyzing, what each of the disciplines in the interdisciplinary study of migration as part of the migration, and can be done, the question is: to what extent migration as a process, a subject of geography? Based on the fact that, along with other migratory movements, emigration is not only human but also geographical mobility, as it takes place in a certain area, it seems that the geography, the most appropriate primary or connect the entire complex, which belongs to the domain of external migration (Banović, 1982).

As we concluded that at this point, no need to deal with methodological issues in the study of external migration, we return to the direct application of certain methods, for which we have pointed out that they are functionally relating to the concept of content and purpose of this study. Thus, the methodological approach meant to conduct research using the observation that the combined method are participating, as well as creating and using the following sources: oral (survey), biographical and written.

In order to obtain representative data in the study, it was planning that the survey covers $2 \%$ of the total number of Serbian and Montenegrin migrants, or about 200 students. In planning the survey sample was applied multistage sample combined quota and random sampling of respondents. In the first stage, villages were selecting that represent migrants in general: Copenhagen, Hillerød, Frederikshavn, Helsingør, Næstved and Silkeborg. The number of respondents in these strata defined on the basis of census survey Rajović Foundation (1993) Adjusted for the number of migrants from the last statement G. Rajović (2011 a). In the second stage, the author of the respondents chose the combination of accidental and deliberate choice, to provide set quotas. Planned number of respondents in the survey implementation was exceeding, but the stricter control logic at the end of the questionnaire dealt with 189 questionnaires, which is a very high turnover of $96.2 \%$ of the planned sample. As this research is still flowing, so were made and new opportunities for exploring higher number of associations or clubs, both by family ties, and through friendly relations. Respondents showed maximum interest, to meet the author and take part in the research.

What contemporary geographic approach aside from the approach of other disciplines, and it is precisely the significance of this research is the emphasis on biographical method or "life story" in which migrants through informal conversation, come up with those data from the life of individuals and communities, which is, to not being able to get just by observation. Because we were interested in the subjective, personal experience of migrants, in this paper transfer "life story" of emigrants on their social life and social relations. After all, "life story" immigrants are the subject of research by many (Stahl, 1977; Clements, 1980; Titon, 1980; 
Robinson, 1981; Bošković - Stulli, 1985; Jambrešić-Kirin, 1995; Stark, 2005; Kovačević and Krstić 2011).

We're studding and written sources, including existing archival records on migrants from Serbia and Montenegro abroad, then press and internet?

In conclusion, we would like to emphasize once again, that the methods used in this research is directly dependent on the topic explanations, and that, as such, an integral part.

\section{ANALYSIS OF RESULTS AND THEIR INTERPRETATION}

\section{1. From the old homeland to a new life}

At this point, showing most distinctive moments from are life and character of the Serbian and Montenegrin expatriates in the time immediately preceding the external migration in Denmark? The main relics in the area of social life were fraternal-tribal and family relationships. The tradition in this respect is so strong, so to say, everyone knows not only the whole range of their ancestors, to the one in which fellowship survives, but to which the other families and clans related and form. At the same time, even though in Serbia and Montenegro, knew and respected the old and respectable fraternity family, yet it democratic spirit and character not made on this basis what was the essential difference between individual families and clans in the tribe. The difference was only basing on reputation, which each gained their way of life, moral properties and relations (Blagojević, 1979).

Relationships within the same fraternity have traditionally been so close to the incredible scale revered and respected kinship, friendship and best men. Within the family, relationships were basing on the maximum parental authority and respect. Highlight and that, during that marriage between a guy and a girl, had a significant influence opinion and certainly parents and other family members, and indeed close and valued friends and relatives, and it is based not only on the health and integrity, but also the quality of family in which the leaves, or from which it comes (Blagojević, 1979).

Distinct from other traditions let us mention just one life cycle, which is calling death. As everywhere else, to come unfortunately more prominent for any young person, but for those who have already been on the verge of death, and more in a car accident or death, but the case of natural death. To conclude this brief overview of the old homeland, our ancestors of today's compatriots in Denmark, the surveys offer guidance to their new life in the Scandinavian plain.

Our research records, based on similar studies Blagojević (1971), pointed out to the fore several important observations about migrants from Serbia and Montenegro:

1. Migrants from Serbia and Montenegro, that the first generation of migrants, mostly from the Timok and northeastern Montenegro started coming in 1964 into one of them completely new, natural and social environment, as it was Denmark. She could barely imagine greater extremes: from a height of several 100 or even a thousand feet, the emigrants went to the Danish plains. They left their agricultural estates and include them in the Danish industrial factories. In addition, all the other circumstances, ranging from climate and soil composition, and through residence to various psychological elements of life, were so different, hence the temptation great and manifold.

2. New residents of Denmark have faced, especially in the beginning, and with many other difficulties. Felt they were already in the first steps, traveling to Denmark and four - five days, with small children in their arms or taking them in hand, and carrying 
in their bags, only some food for the journey and personal wardrobe. Nonetheless, were neither difficulty getting used to the new way of employment, housing, nutrition, lack of Danish language, the uncertainty in the work, homesickness, loneliness. How all this explains some survey respondents "When we arrived in this Promised Land, we felt as if we have fallen from the sky"1 (fi-gen.-m.1940).

3. Forty years have elapsed from the date of arrival to the first generation of migrants from Serbia and Montenegro in Denmark, so that these people and their families demonstrated and proved, as with all the difficulties that they had. In addition, certainly were not small, brave their work, to survive in the soil of Denmark and challenge many sympathies to the Danes themselves, and all other. During their stay in Denmark changed the mentality of migrants. Developed a reasonable sense of reality, developing organizational skills and strong preference for are work. Increasingly appear strong willed personality. Everyone is adapting to new ways of life. When asked what the highest prices at the Danish man and what you learned from them, followed by the surveyed respondents described the answer: "The responsibility of self, family, society, work and attitude to work"(fi-gen.-f.1944).

4. Today, migrants from Serbia and Montenegro Scandinavian in this country have achieved great success in every way, from personal, family to social. According to what can be observing and seen, the standard of living migrants in Denmark are indeed very high. Nearly all of them have very nice comfortable apartments, equipped with the most modern furniture and home appliances. Individually, each family owns a car. From the individual interviews, we learned that most of them possess built the house in their homeland or purchased apartments and commercial space owners are mostly in Belgrade, Novi Sad, Podgorica, the Montenegrin coast. Also, a number of migrants' identity savings "old savings" that they have been frozen 27.04.1991, and today stand as worthless. Foreign depositors consider that the latest Act of 2004 restitution funds by 2017 does not mean anything to them, because they emphasize that many of them would not be alive. "Time is not working for us. Indeed, we expect from our government to take the right measures and resolve this issue in the right way "(fi-gen.-f.1942). One gets the impression that the Serbian and Montenegrin expatriates in Denmark have all the conditions to their lives. Monthly payments are between 11,000 to 13.0000 DKK. As a rule, are nuclear family, work and a husband and wife? If the three-member or multi-member nuclear family is only one of the spouses, are material arrives monthly assistance commune (municipality). Such a family is no shortage of food, clothes and shoes. Such are the Danes, who on all the details take care, down to the finest detail.

5. The main driver in this entire journey, from arrival and stay in Denmark there is now, undoubtedly Danish society. Danish operate shows considerable aptitude and a strong will to - to contribute to the social and economic development of their country. Accustomed to the business discipline and clarity in observation, Danish employers have enthusiastically embraced migrants from Serbia and Montenegro in the workplace, of course, and their willingness, energy, cheerfulness, sense of reality all in terms of adjusting to a new lifestyle. Danish employers and you have noted that the Foundation, more sense of proportion, a sense of humor. Everything they do not like, it is a public joke and laughter. On the other hand, according to Danish migrants to

\footnotetext{
${ }^{1}$ Symbols used in the text: fi - the first generation migrants, se- the state second generation, th- third generation markets, m-male, f- female; 1940 - birth year.
} 
employers is a very lively sense of gratitude for the services, which can often turn into a nearly limitless trust. Thanks to its organizing capacity many migrants from Serbia and Montenegro now in Denmark, having become highly productive workforce. Today they are the ones who manage, make decisions, hire and products.

\section{2. Occupational mobility}

As one of the factors of social integration of migrants from Serbia and Montenegro in Denmark, is, and their vertical mobility. Certainly, I do not have any vertical movement, but one that brings a higher social position, i.e. front vertical mobility. It is also one of the assumptions and motives of foreign migration. It is mostly the consequence and its effects (Kilibarda, 1979).

Evaluation of occupational mobility, we present the basis of the procedure is applied only Kilibarda (1979), and is based on the question of whether changes in interest communities, mean input vertical occupational mobility and whether the Serbian and Montenegrin migrants in Denmark experience.

To answer this question, one should compare the old homeland of the present position of migrants and migration. Certainly, we will use the interpretation Blagojević (1971), which is consistent with our analysis "Running out of hard mountain life, filled with every kind of privation and efforts to combat not generous nature. And seeking a better country and easier living conditions ... population went wherever there was some hope and seems to be with my family ... able to arrange for a safer and better life ". Phenomenon described by noted author, certainly influenced this external migration, but also on the social mobility of the Serbian and Montenegrin migrants, including their professional mobility. Survey research is categorizing in this case for the first generation migrants, given that the second almost did not have with their homeland any professional orientation.

It known that most of the migrants from Serbia and Montenegro were solely related to agricultural professions in general, and in consequence thereof, the external migration in Denmark, meant a change of occupation. This shows our research records, almost all members of the first generation of Serbian and Montenegrin expatriates in Denmark become industrial workers.

Own Former and current work can be evaluated from economic point of view. Respondents, mainly stating that their greater economic benefit jobs that have had or now have, from agricultural production they had in their homeland. In line with the assessment of the economic benefits and advantages given the current place of migration, first generation migrants provide similar advantages in terms of labor productivity. Even at first glance, it becomes clear that the jobs now performed or performed, the respondents brought greater economic benefit and that higher productivity in relation to the activities of farmers, which they have done in their homeland.

Giving priority to the current place of migration (modern working conditions in the industry), over the hearth (undeveloped agriculture, livestock), the respondents had in mind the criteria of modern agriculture (small, under-fertile gardens) and low labor productivity (farming plow, plow, harvest sickle ....).

In terms of interesting work, we conclude that most of the members of the first generation of Serbian and Montenegrin migrants preferred activities currently carried out or performed in relation to the tasks that are performing in our country. Opinions are largely confining to the economic benefits, productivity and dignity. Jobs that done in the country, and those who have been a small number of members of the first generation of migrants 
performed on Jutland, concerning agricultural production, according to respondents, are different in terms of knowledge. Specifically, a farmer in Denmark possesses the literature, which is used extensively applied and theoretical knowledge in practice. Local government organizes seminars, which the farmer must attend, and the results are applying to agricultural possession. "No land, not one year not sew the same culture and the previously studied the productivity of land and do not accurately examine the composition and amount of fertilizer needed... Each specimen is carefully composed menu for the week... .

This kind of work and attitude toward work, this small country by population, but by wisdom and great job ranks as the first in the world in the production of meat, milk, eggs and other food - agricultural products " (Rajović, 1993).

In conclusion, our findings go in the direction that the first generation of Serbian and Montenegrin migrants preferred jobs they now have. Or have had in relation to agricultural activities, which are performed in our country in terms of productivity, accountability, of interesting, economic benefits, so it is not difficult assume that like-minded and with mark of social prestige and importance. Sure, it is obvious that the first generation respondents Serbian and Montenegrin migrants, rightly, point to the vast differences of social significance that have agricultural producer in the country of migration, compared to the native land.

In the process of transformation of migrants into the modern producer in the country of migration, comes many changes that are to a greater or lesser extent, the subject appears in the work and in life. In this respect, are place and the business changes and adapting to the new organization of work, which is different from agriculture in our country? During the changes of mentality, which understood as a type of behavior and thinking? This is determining by the appropriate changes in the conditions of work and life. In addition, here again, removed the discrepancy between the role and mentality, especially because of the presence of discord, non-industrial mentality. One of the consequences of social integration and occupational mobility and self-confidence is to be in the industry, as well as in other areas of economic operation, can be successfully organized life, and develop relationships with the homeland and preserving the memory of it.

Transformation process migrants characterized and by a specific traditional and contemporary solidarity. Mutual Solidarity Foundation is at a high level. Help was varied, from the individual during various surgical intervention, family, on the death of its members, to help their homeland, when building ambulances stations, sports courts, renovation of school buildings. Best explains one-survey respondents: "When we arrived in Denmark, we did not let someone give in, that we had, and we shared. We today, when we live well, do not forget each other. If one of us buys a car or a property, not a problem to provide is money.

We give loan Interest-free credit, so when can, give it back" (Rajović 1993). Help, there is an in drugs and various medical devices, hospitals across Serbia and Montenegro and attachments for the construction of the church the Temple of Saint Sava in Belgrade... Alternatively, to turn out Antonijević (2000) in complex organization glamorous celebrations - weddings, baptisms and departures to the army, which was particularly important during difficult economic situation in Serbia and Montenegro nineties? And not only that, but it is also the source continuously, until the present day, and those that benefited from the remittances of our communities, which is why they can be considered the most successful decades of export product in the former Yugoslavia and present-day Serbia and Montenegro (Dobrivojević, 2007 and Nikolić, 2009). 


\section{3. Visiting other churches and ecclesiastical ceremonies}

In Denmark by 1998, there was no Serbian church, and therefore migrants went to the Russian church of Saint Alexander Nevsky in Copenhagen. Establishment of parish of Saint George is certainly the most important event in the history of the existence of the Serbian Montenegrin community in Denmark. Officially recognized by the Danish government in August 1998 and the next 1999 parish began with spiritual work on location Blagards Plads 6A in Copenhagen. Otherwise, are parish belongs Eparchy British - Scandinavian Serbian Orthodox Church and parish activities near Copenhagen will be done in the cities Næstved and Silkeborg.

It is evident that in the early nineties of the last century, there was a revival of religious society. There are various motives of going to church, go to one of the traditional reasons, others perceive it as a community, within which they can achieve their very existence, and third, leaving occasionally to worship, just because you can feel the relaxed and friendly. The fact is that an increasing number of Serbian and Montenegrin migrants in Denmark back in the arms of the church.

On the question of whether you go to church. Followed by the answer of respondents:

a) "I like to go on Sundays, before the liturgy begins to burn candles and pray for the health of my closest and forgiveness of sins. When the liturgy begins, I feel a kind of energy that calms me down incredibly. In some moments, the tears start. Feeling at the end of the liturgy, I cannot describe. Simply i do not know that i would say was use. Which would have been adequate to my happiness" (fi-gen.-f.1948).

b) "We recently my company and I have introduced some of our rule that, whenever we can, on the weekends, we go to church. After each stay in it, i feel rather it is hard to describe just wonderful "(se-gen.-m.1971).

c) "I do not go to church, everything looks theatrically "(th-gen.-f.1989).

That the Serbian and Montenegrin migrants' increasingly returning church teaches us, and the most joyful celebration of Christian holidays - the resurrection of the Lord Jesus Christ, 2007. Parish of Saint George in Copenhagen was too small to receive all the Orthodox believers. The Easter matins started back in the early evenings, confessing believers in communion, to be continuing at midnight procession three times around the church. Liturgy of are Easter Holy Communion continued and awareness Easter eggs. Archpriest Radmila Stokić particularly pleased by the fact that in the early morning hours at the Eucharist was and lots of children, students supplementary school "Sveti Sava", but the younger ones who are not yet up to the school, but they still remained awake (www.srpskadijaspora.info) .

Here are imposed question, how are Serbian and Montenegrin expatriates trusting people or religious holidays are just a pretext for engaging in folk customs and traditions. Thinking Živković (2007) is as follows: "Regardless of the fact that more and more migrants declare that they are believers, there is tacit selection on authentic secularized and so-called believers. First, aim church life that speaks through the spirit of unity, as genuine sociability, personal self-restraint, repentance, sacrifice, mercy, truth, justice, and above all, love. Second followed by secularized forms of life and remain in are possession of a superficial, external, ritual, folklore and even marketing layer Vera, which brings into question the essence of religion. Because the law is applied on human spirituality is a huge personal accomplishment, sustained effort that overtakes their entire being, and without which no true salvation". Without doubt, one of the ideas rectories of Saint George goes in the direction of organizing family gatherings at the church. Family picnics meant as a casual friendship with the parents and children we prepared an educational program, sports and entertainment. 
Families come to the liturgy, attended a casual luncheon, and then hold a lecture for adults and children, or show occasional movie. After those families socialize, participate in some sports, walking by the lake... Overall, parishioners spend a day in prayer, education, social and sports activities (www.pravoslavlje.org.yu). The idea, however, is good and helps with one hand, spiritually strengthen parishes, and on the other, both individuals and families of migrants.

Survey research shows us that the Serbian and Montenegrin migrants' loss of identity seen in the direction of loss: religion, traditions, language, customs and culture. Featured answers are members of the first, second and third generation migrants, according to the categories of religion, tradition and upbringing:

a) "Faith in god faith in honesty"(fi- gen.-m.1945).

b) "Respect and maintain the traditions, customs and visit home"(se-gen.-f.1963).

c) "School tolerance home education"(th-gen.-m.1984).

"Life Stories" migrants, survey and documentation available, the authors of this paper follows the conclusion that Serbian and Montenegrin migrants in Denmark, generally do not have any plans regarding the length of stay in this country, much less with any investment in our country. The current Danish politics in favor of migrants and in different ways helps to preserve identity. In the first and second-generation migrants to assimilation has not occurred, except that the second generation successfully integrated into Danish society. For the third generation of the election to the extent that will maintain contacts with the country of origin of their parents and to preserve the tradition.

\section{4. Activity in communicating through the media (newspapers, TV, Internet)}

In addition to disseminating information, the media have a role in the integration of society, and the intensification of consciousness of belonging to an ethnic group, the impact on the socio - economic life, as well as the maintenance that is, changing cultural values. The main activity of the media - the Diaspora, should be directing towards informing migrants of all economic systemic issues in the country of origin, which are of importance for members of the Diaspora, as well as assistance for their active participation in the socio - economic trends (www.cbhif.net).

The migrants from Serbia and Montenegro who live and work in Denmark, we noticed, were not adequately informed about events in their homeland, and not even are country of origin does not know enough problems of migrants in our country of migration. To this end it is necessary to consider the basic problems faced by local media and Diaspora met in this business, and ways to overcome them, primarily through better links with the institutions, and the media in the country of origin, which would significantly improve the information Serbian and Montenegrin migrants in Denmark.

The main mission of the media should be directing towards the preservation of identity and information about events in their homeland. When it comes to media users, or subjects, half of them said that the media in Serbia and Montenegro, the main source of information. Most respondents stated that follows the programs of Serbian and Montenegrin media of Diaspora and most programs are mentioning: "Radio-Television of Montenegro", "RadioTelevision of Serbia", "Radio-Television Pink". In addition, the results show that, even a Serbian and Montenegrin media does not have an office or bureau in Denmark. One respondent interviewed it this way: "Without full presence of the media, the queen cannot be effective, nor the Diaspora cannot be informed"(se-gen.-m.1977). 
Most of the print media on the Internet in Serbia and Montenegro was opened for reading, while paying for access to cherish now weeklies:" NIN" (www.nin.co.yu) and "Time“ (www.vreme.com). However, on their website of the texts, can be read for free, subscription only applies to the entire contents. Free content offer weekly "Economist" (www.ekonomist.co.yu), while some other popular weeklies such "Daily Telegraph" (www.nedeljnitelegraf.co.yu) and sell only selected text. From the presentation of the print media, it is worth noting dailies: "Blic" (www.blic.co.yu), „Voice of the public" (www.glasjavnosti.co.yu), "Today" (www.danas.co.yu), "Evening News" (www.novosti.co.yu), " Diary Novog Sada" (www.dnevnik.co.yu), "Podgorica News" (www.vijesti.cg.yu), "Day" (www.dan.cg.yu)..... Would be unjust to bypass, "Politics" (www.politika.co.yu), whose website (the house with the longest tradition of journalism), in this part of Europe substantially below expectations (www.mediaonline.ba).

Already from this quite superficial enumeration, it is clear that in Serbia and Montenegro, there is no Internet journalism in the true sense of the word. That is, there is no Internet media, and internet presentations of existing media do not provide the Serbian and Montenegrin migrants, any more than its regular production. Internet newsroom that there are some major media deal mainly with technical work, transferring existing content on the Internet, and they are rarely befalls a journalist whose job it was to these contents, even if the Internet adapts specifics. Currently, the presentation of newscasts media in Serbia and Montenegro is intending more for the intellectual elite, but for the Diaspora (www.mediaonline.ba).

In the course of establishing better communication through the media, between the migrants and the need to:

1. Activity in communication through the media is a two-way between nut - Diaspora,

2. Actively involve the public services of Serbia and Montenegro in the process of cooperation and exchange of materials that would make available to the media in the Diaspora,

3. Establish Internet archive material from which the media in the Diaspora can draw content (articles on monuments, important historical events and personalities, traditions and contemporary culture, creativity, music),

4. Promote greater use of online media issues in the Diaspora, but also in the country of origin,

5. To raise awareness of the possibilities and specifics of online journalism, in order to realize the potential of the Internet for better coordination, not to be seen as an obstacle to the Internet (including WAP, podcast and RSS option on website),

6. The introduction of more multimedia and interactive elements to websites, which contain the ability to combine text, pictures, audio-database,

7. Need more understanding of the needs, particularly third-generation migrants, which is more inclined towards high-tech solutions online. Both in terms of form, and in terms of content,

8. It is necessary to develop the program (program), dedicated to the children of migrants and

9. In terms of content and target groups, the media in Serbia and Montenegro and in the Diaspora must have a dual role-information and preserve cultural, language and national identity (www.negotin.org.yu).

As we have noted in interviews with respondents surveyed are majority of the first generation of Serbian and Montenegrin migrants, the news, releases somewhat, while members of the second and third generation, commonly used internet. Here is how the 
respondents of all three generations of migrants, they formulated the following reasons for the media:

a) "In order to be informed about is situation in our country, always watch diary"(figen.-f.1942).

b) "Sometimes I read "News," "Evening News," "The Day" (fi-.gen.-m.1949).

c) "Mostly i follow sports press and Internet"(se-gen.-m.1967).

d) "Mostly, I watch the internet and reading women's magazines" Health and Beauty "," Gloria "," Story "(se-gen.-f.1973).

e) "Internet Only" (th-gen.-m.1987).

f) "Internet" (th- gen.-f.1990).

From the responses of the first generation, it can be concluding that the most commonly used television as the means of information, and at times the daily press. The secondgeneration migrants, mostly follows sports and women's magazines and internet part, the third generation, based solely on are internet.

\section{5. Linking social and community networks and the broader environment}

Social networks involve interactions between individuals or groups of people. The smallest group of social cohesion that occurs within the family, according to a labor survey estimate can be concluding that most of the free time Serbian and Montenegrin expatriates spend mostly with family members. In composition or size, family Serbian and Montenegrin migrants generally "makes union - husband and wife, nuclear family - a married couple and their children, extended family - parents, children, grandchildren, relatives of the first degree, a kinship community - collateral relatives" (Haider - Labudović, 2007). Most of the migrants interviewed at home celebrating birthdays, the birth of a child, moving into the apartment, Woman's Day, New Year's Day. None of our ceremony cannot be imagining without a bottle of alcohol (Serbian and Montenegrin tradition), flower (Danish custom) and gifts for kids (chocolate candy) and other valuable gifts. Almost all migrants know each other and know who is where and when it arrived in Denmark. Have been recorded, and the numbers each other, and is used by the directory, free of charge, which is given to every owner of a phone number in Denmark. Family and kinship relations among the migrants are very highly developed. The migrants maintain close ties with their relatives "neighbor", not only in Denmark but also to those who live in Sweden and Germany. Not forgetting even relatives who remained in the homeland and mutual visits are frequent, especially during the holiday season, which many migrants spend in the homeland. Friends of the respondents were mostly migrants from the former Yugoslavia, although none of the respondents did not rule, nor in any other negative way distanced him from socializing with strangers. According to data Rajović (2011a) to connect with strangers only migrants from Montenegro with members of Danish nationality, resulting in the signing of 79 marriages (41 Montenegrin woman married to a Dane, Dane married 38 Montenegrins).

Wider connection Foundation takes place within the institution, or association in which migrants are social connections to be basing on mutual inclination, to sports or cultural activities in which migrants work for less or more active participation (Haider- Labudović, 2007). Within both the Association Foundation, and individual clubs, special importance is given to activities in the various sections. One respondent explained it this way: "Many of the sections they found a spot for themselves, which has come to the fore both social and creative work and to connect people based on common interests and preferences"(fi-gen.-m.1946). 
As seen in sections of activities, and other first-generation migrants, we show in the following examples:

a) "Sports section is the most frequent. Our traditional love for the sport, and there came to the fore. A variety of training and matches marked the life and work of those genes is a sport " (se-gen.m.1969).

b) "Folklore section is also included a large number of our boys and girls. Through their activities in folklore show to know how to conserve and preserve their cultural traditions " (se-gen.-f. 1967).

c) "Youth section has provided an opportunity to create a youth themselves living in Denmark, as it suits them. They managed to make a series of cultural and sporting events, where they can gather and have fun " (se.gen.-f.1972).

d) "Translation section was available for all our people, which was a help in translation" (fi-gen.-m.1941).

e) For expatriates surveyed expressed a wish of unity, harmony and friendship:

f) "It would be nice if it opened centers in which our young people to hang out, like we used to" (fi-gen.-f.1956).

g) "If our children do not forget who they are and where they" (se-gen.-f.1975).

h) "To get along and hang out, like our parents" (th-gen.-f.1988).

In relation to the wider environment and the Danish population, social relations been established mainly in the workplace, where individuals connect related occupations. "Migrants gladly invite their colleagues from work on holidays such as the Family fame.

What in relation to homeland lacking in social relations, neighborhood ties are characteristic of the homeland" (Haider - Labudović, 2007). The second and third generation migrants, established relationships diverse in relation to are wider environment than their parents are. There are two main reasons for this: a better command of the Danish language and Danish attending schools in which students of different nationalities. Members of the second-and third-generation migrants, in addition, still most of the free time in the Diaspora institutions, which maintain and confirm its origin (Davidović, 1999).

Consumer survey focused on the question: "What do you associate in Serbia and Montenegro?", Led to a response that indicates, that the respondents generally binds to its origin, that is, the area from which they originate, relatives, stay in Belgrade, on the Montenegrin coast, visiting monasteries, historical figures .... Very important way of preserving the identity of migrants and its transmission to new generations is the organization of schools for children of Serbian migrants (only in 2005 started to work additional classes in Serbian school "Sveti Sava", under the auspices of the Serbian Orthodox Church in Copenhagen). In addition, the supply of good quality textbooks, then courses in culture, history, literature and learning about biographies of famous writers, scientists and artists.

It should all be encouraged and organized by country of origin of migrants in Denmark, but also in Serbia and Montenegro (summer camps, visits, excursions, exhibitions ....). In this sense, a good example of non-governmental organizations "KAROM" from Sremski Karlovac, which represents the school of Serbian tradition? Her team of teachers is ready to travel to the places where they live our migrants and to offer a three-day or five-day courses in Serbian language, literature, history, religion, and ethnology (Bobić, 2009). 


\section{CONCLUSION}

For many years in the former Yugoslavia "voice" of workers - foreign workers was silent, among other things because of their ambiguous status and repeatedly emphasized the fact they're going to give temporary work in Western Europe, meant "escape from the socialist paradise cal," i.e., an indicator of failed economic reforms, unemployment and poverty of the population engaged in agriculture. On the other hand, there was ideologically ambivalent attitude towards the party leadership Yugoslavia guest workers: initially viewed as "traitors" and potentially "easy target" for the ideological influence of communism enemy migration during the late sixties and seventies. Almost casually and "frown upon" the uncontrolled exodus of workers - foreign workers, apparently representing a burden for the economy of underdeveloped countries that "could not absorb the pressure of workers newly arrived from the countryside" (Dobrivojević, 2007). However, workers from Serbia and Montenegro in the mid-sixties went to work temporarily in Denmark, with the intent to return when we have enough material resources to live in their homeland. However, there was dissolution of the former Yugoslavia, the economic blockade of the country of origin, so that the conditions for return have been more favorable, although nearly twenty years ago and in the meantime, unplanned extended stay. It is quite understandable, and then by the desire of at least some of them: the difficulties and efforts, results and success of Serbian and Montenegrin expatriates in Denmark, and the record is highlighting in this study. In addition, the support of the state of Denmark and the Danes was not lacking. Hence the author who has, a lot of sympathy for this country and its people. Who is understandable, since he lives in Denmark narrower part of our family and the wider family?

Our research evidence outlined in the foreground, a few obvious observations regarding the Serbian and Montenegrin expatriates in Denmark:

- First, that the first generation of Serbian and Montenegrin migrants (mostly men), characterized the planned temporary stay, which in most cases extended in a manner that is brought to her husband, and then the whole family in which the children continued their education in earth moving;

- Second, the situation with members of the second generation is much different. They are confronting with two cultures; increasingly adopting the language and value system of the country where they live, what they ultimately facilitates and enables social mobility;

- Third, in Denmark to form a third generation, significantly different from are first, more integrated into Danish society than the other is. So that the phenomenon of gender, are unlikely to be decisive for the future, at least not in large numbers, while the only recent organized additional classes offered opportunities to learn their mother tongue - Serbian language, geography, history and music education;

- Fourth, a significant role in the identification of the Serbian and Montenegrin migrants in Denmark are in the family, relatives, churches, associations and clubs, where they can develop their activities and connections within the community;

- Fifth, in the field of ethnic labels (language, church, customs, material culture, folklore), surveyed respondents are trying to faithfully abide by the tradition that binds them to the homeland and origin. The views they have on cultural heritage, is no different from what in their homes and clubs practice. About homeland, members of the first generation of happy talk, and beaming, and other members, or a third, even though you might feel the same, so do not show your nostalgia;

- Sixth, the integration into Danish society is moving towards the establishment of harmonious relations between the Serbian and Montenegrin settlers and the Danish 
population, while "cultural pluralism" implies both the existence and coexistence of multiple cultures in this Scandinavian country.

Denmark is a prime example of the state where the persistent and deliberate work, culture and democracy achieved legally, economically, socially stable society, appealing to other countries and peoples. In such a society, and that its place have Serbian and Montenegrin expatriates, according to which the Danes have a lot of sympathy, which is understandable when the Danes themselves and retaliate correctness of Slovenia's emotions.

Results that we announced in this study represent a modest contribution to the study of the phenomenon of Serbian and Montenegrin Diaspora in Denmark. On this occasion, we told only a minimal number of research findings and the fact that we obtained during field research. We hope that the above-mentioned results encourage further, more profound study of this complex and important issue, and that this research, to achieve its purpose and be of benefit to all those who want to familiarize themselves with the topic of the Serbian and Montenegrin Diaspora in Denmark.

\section{References}

[1] Group by Montenegrin Diaspora, Proceedings of the Montenegrin Association Foundation, the Center for expatriates of Montenegro, Podgorica, 2006, pp. 4-5.

[2] Vukčević M., Causes and general characteristics of the Montenegrin Diaspora, Proceedings of the Montenegrin Diaspora, Center for expatriates of Montenegro, Podgorica, 2006, pp. 15.

[3] Penev G., Knowing our citizens working in abroad and returning to the country. Census of Population and Housing 2011, Symposium "Census 2011", Proceedings, London, 2-4 April, 2008, pp.112-116.

[4] Statement V. Radulović, Ambassador of the State Union Serbia and Montenegro in the Copenhagen newspaper "Blic". Available from: http://www.blic.evropa.net (26.08 2005).

[5] Haider Labudović I., Serbian Diaspora in Vienna in the latter half of the twentieth century, Ph.D. thesis, (manuscript), Belgrade 2007.

[6] Rajović G., Montenegrin immigrants in Denmark, "The Agency PC system", Belgrade, (2011 a).

[7] Rajović G., Demographic characteristics of the modern labor migration from Montenegro to Denmark, GeoScape 6(1-2) (2011) 2-10, (2011 b).

[8] Marković P., Gastarbeiters as the Factor of Modernization in Serbia. Twentieth century history books 2, Belgrade 2005, pp. 145-163.

[9] Baučić I., The origin and structure of workers from Yugoslavia to Germany, Institute of Geography, University of Zagreb, Volume 9, Labor migration, Book 1, Zagreb, 1970, pp. 33.

[10] Rodić P. D., (1972). Journal of Science, University of Belgrade, Institute of Geography, Belgrade, XIX (1972) 63-80. 
[11] Rodić P. D., (1971). Journal of Science, University of Belgrade, Institute of Geography Belgrade XVIII (1971) 143-159.

[12] Pejović Đ., Montenegrin emigration in the nineteenth century, Cetinje, 1962, pp. 5-56.

[13] Drljača D., View of Ethnology Polish and Yugoslav postwar migration tests, the Ethnological Survey, Belgrade, 5 (1963) 81-90.

[14] Božović G., Serbian economic emigration to the West, the Bureau of the Republican Executive Council on Foreign Relations, Belgrade 1968.

[15] Lutovac V. M., Labor migration Montenegro to temporary work abroad, $\mathrm{Ph} . \mathrm{D}$. thesis, (manuscript), Belgrade 1975.

[16] Grečić V., Contemporary labor migration in Europe, "IMPP", Belgrade 1975.

[17] Majstorović S., In search of an identity, "Word of Love - education ", Belgrade 1979.

[18] Petković Lj., Problems of international labor migration with special reference to Yugoslavia, "Scientific Paper", Belgrade 1988.

[19] Petrović R., Migration of the Serbs in SFR Yugoslavia after World War II, migration of Serbs now and then, "IMPP", Belgrade 1990.

[20] Davidović D., Journal of Ethnographic Institute Serbian Academy of Arts and Sciences 43 (1994) 101-109.

[21] Grečić V., Lopušina M., All Serbs of the world, "Principle", Belgrade 1994.

[22] Đokovic-Srdić Lj., Development of Yugoslav external migration, Yugoslav Survey Number 3, Belgrade 1995.

[23] Grečić V., Kutlača Đ. G., Matejić V. Č., Mikic O., Migration of highly skilled personnel and scientists from the Federal Republic of Yugoslavia, Federal Ministry of Labor, Health and Social Policy, Belgrade 1996.

[24] Gabrić-Molnar I., Dimensions and economic effects of the Yugoslav population migration abroad, Faculty of Economics, Subotica, 1996, pp. 61-66.

[25] Davidović M., Children of foreign workers - the second generation of Yugoslav economic migrants in Western Europe, Institute of Social Sciences, 1999, pp. 22-41.

[26] Pavićević A., Journal of Ethnographic Institute Serbian Academy of Arts and Sciences LII (2004) 129-137.

[27] Kalezić Ž., Structural changes in the Montenegrin village in the twentieth century, NIP "Victory", Titograd, 1976, pp. 53-65.

[28] Rajović V., Montenegrins in Denmark, "Unireh", Nikšić, 1993, pp. 37-91.

[29] Banović B., Emigration from Yugoslavia and the Yugoslav immigration to New Zealand, Ph.D. thesis, (manuscript), Ljubljana 1983.

[30] Stahl S., Journal of Folklore Institute 14(1-2) (1977) 9-30.

[31] Clements W. M., Western Folklore 39(2) (1980) 106-112.

[32] Titon J. T., Journal of American Folklore 93(369) (1980) 276-292.

[33] Robinson J., Journal of American Folklore 94(371) (1981) 58-85. 
[34] Stulli - Boskovic, M., Literary Criticism 5 (1985) 137-164.

[35] Jambrešić -Kirin R., Folk Art 32(2) (1995) 165-187.

[36] Stark L., Ethnologia Fennica (32) (2005) 44-47.

[37] Antonijević D., Ethno-anthropological problems 4(1) (2009) 13-35.

[38] Blagojević O., Bačko Dobro Polje - Highlanders in the plain (old homeland in the book), Ethnographic Institute of the Serbian Academy of Sciences and Arts, Book 18, Belgrade, 1979, pp. 88-94.

[39] Kilibada K., Bačko Dobro Polje - Highlanders in the plane (social integrations and professional mobility in the book), Ethnographic Institute of the Serbian Academy of Sciences and Arts, Book 18, Belgrade, 1979, pp. 203-210.

[40] Blagojević O., Beer, a special edition of the Serbian Academy of Arts and Sciences, Volume CDXLIII, Department of Social Sciences, book 69, Belgrade, 1971, pp. 437.

[41] Kovačević I., Krstić M., Between history and modernity: an anthropological study venation of foreign workers in the 21 Century, ethno anthropological problem, Number 4, Belgrade, 2011, pp. 969-981.

[42] Dobrivojević I., In search of prosperity. Departure of Yugoslav citizens to work in Western Europe 1960-1977, History 20 century, books 2, Belgrade, 2007, pp. 89-100.

[43] Nikolić G., Journal of reviewing the past to review past 7(4) (2009) 69-84.

[44] Serbian Diaspora, Available from: http://www.srpskadijaspora.info( 19.09 2008).

[45] Živković B., Interview "How do our immigrants believe people”, 2007, Available from: http:// www.vesti.de ( 12.10 2008).

[46] Parish of Saint George in Copenhagen. Available from: http://www.pravoslavlje.org (11.11 2008).

[47] Media and Diaspora. Available from: http:// www.cbhit.net (19.11 2008).

[48] The print media in Serbia and Montenegro.

Available from: http://www.mediaonline.ba ( 03.12 2008).

[49] Internet operational link between the homeland and the Diaspora. Available from http://www.negotin.org.yu (25.12 2008).

[50] Bobić M., Sociological Review XLIII(3) (2009) 361-377. 